\title{
Study on yield potentiality and spatial requirement of rice varieties (Oryza sativa L.) in system of rice intensification (SRI) under red and laterite zone of West Bengal, India
}

\author{
Kalyan Jana $^{1^{*}}$, G. K. Mallick ${ }^{2}$, S. Ghosh ${ }^{2}$ and G. Sardar ${ }^{2}$ \\ ${ }^{1}$ Directorate of Research, Bidhan Chandra Krishi Viswavidyalaya, Kalyani- 741235, Nadia, West Bengal, INDIA \\ ${ }^{2}$ Rice Research Station, Bankura - 722 101(West Bengal), INDIA \\ ${ }^{*}$ Corresponding author. E-mail: kjanarrs@gmail.com
}

Received: October 8, 2014; Revised received: March 18, 2015; Accepted: May 7, 2015

\begin{abstract}
Field experiment was conducted at Rice Research Station, Bankura during kharif season 2009 and 2010 to study the yield potentiality and spatial requirement of rice varieties in system of rice intensification (SRI) under red and laterite zone of West Bengal. The experiment was laid out in a randomized complete block design (RCBD) in a three replications with two rice varieties (Swarna and Lalat). Performances of swarna and lalat varieties in SRI as compared to conventional method of rice cultivation (CMRC) were investigated. Swarna (MTU 7029) has yielded maximum grain yield $(6.07,5.66$ and $5.86 \mathrm{t}$ ha-1 during 2009, 2010 and in pooled, respectively) from the treatment T7 (25 $\times 25 \mathrm{~cm}$ spacing) under SRI. Lowest grain yield (3.55, 3.23 and $3.38 \mathrm{t}$ ha-1 during 2009, 2010 and in pooled, respectively) was recorded from treatment T9 (Lalat at $20 \times 15 \mathrm{~cm}$ spacing) under CMRC. SRI technology has potential in increasing more grain yield, it saves seed requirement and irrigation water and chemical fertilizer considering than conventional method of cultivation. Rice cultivation is more sustainable and profitable for the farmers in SRI under the red and laterite zone of West Bengal.
\end{abstract}

Keywords: Grain yield, Plant-hill spacing, Rice cultivation, Rice intensification, Sustainable system

\section{INTRODUCTION}

The System of Rice Intensification (SRI) is a new methodology for increasing the yield of rice. It was developed in 1983 by the father Henri de Laulanie in Madagascar. SRI is a combination of several practices that include slight changes in nursery management, time of transplanting and management of water, nutrients and weeds. Though fundamental practices remain more or less same, SRI emphasizes certain changes in agronomic practices from conventional method of rice cultivation (Satyanarayana, 2004).

SRI methodology involves a set of practices in nursery, soil, water, plant and nutrient management. The convergence of changes in the way that plants, soil and water are best managed and produced is what is known as the as the System of Rice Intensification. Sinha and Talati (2007) reported that SRI increased rice grain yield as compared to conventional method of rice cultivation by $32 \%$ in West Bengal, India. Sato and Uphoff (2007) reported that 78\% increase in average rice yield under SRI with reduction of $40 \%$ in water use, $50 \%$ in fertilizer and $20 \%$ in cost of production as compared to conventional method of rice cultivation in Indonesia. Jana et al. (2015) reported that grain yield was significantly higher in SRI than conventional method of rice cultivation. Mc Donald et al. (2006) analysed data from 40 sites from different countries including China, Nepal, Madagascar, Thailand, India, Sri Lanka, Bangladesh, Philippines and Indonesia and reported that 24 of 35 sites demonstrated inferior rice yields with SRI than with best management practices of rice cultivation. Farmers and researchers have reported that yield increases through SRI of 1.5 to $2.54 \mathrm{t} \mathrm{ha}^{-1}$ in Tamil Nadu and Andhra Pradesh (Satyanarayana, 2004; Thiyagarajan et al., 2005). Sinha and Talati (2005) also reported in the IWMI TATA study a saving in water, an increase in straw yield by $50 \%$, labour productivity increased by $43 \%$, with net return increase by $67 \%$ in Purulia, West Bengal, India. SRI creates favourable micro-climates conditions for plant growth (DRR, 2011). Better root growth and proliferation in SRI and also opportunity to extract water and nutrients both from larger soil profile area, which in turn improved synthesis as reported by Barla and Kumar (2011). Therefore, the present study was undertaken to study the yield potentiality and spatial requirement of rice varieties (Oryza sativa L.) in system of rice intensification (SRI) under red and laterite zone of West Bengal, India.

\section{MATERIALS AND METHODS}

Filed experiment was conducted comparing SRI and 
Table 1. Treatments details.

\begin{tabular}{cccc}
\hline $\begin{array}{c}\text { Treat- } \\
\text { ments }\end{array}$ & Variety & Spacing & $\begin{array}{c}\text { System of } \\
\text { Cultivation }\end{array}$ \\
\hline $\mathrm{T}_{1}$ & Lalat & $20 \mathrm{~cm} \times 15 \mathrm{~cm}$ & SRI \\
$\mathrm{T}_{2}$ & Lalat & $20 \mathrm{~cm} \times 20 \mathrm{~cm}$ & SRI \\
$\mathrm{T}_{3}$ & Lalat & $25 \mathrm{~cm} \times 25 \mathrm{~cm}$ & SRI \\
$\mathrm{T}_{4}$ & Lalat & $30 \mathrm{~cm} \times 30 \mathrm{~cm}$ & SRI \\
$\mathrm{T}_{5}$ & Swarna & $20 \mathrm{~cm} \times 15 \mathrm{~cm}$ & SRI \\
$\mathrm{T}_{6}$ & Swarna & $20 \mathrm{~cm} \times 20 \mathrm{~cm}$ & SRI \\
$\mathrm{T}_{7}$ & Swarna & $25 \mathrm{~cm} \times 25 \mathrm{~cm}$ & SRI \\
$\mathrm{T}_{8}$ & Swarna & $30 \mathrm{~cm} \times 30 \mathrm{~cm}$ & SRI \\
$\mathrm{T}_{9}$ & Lalat & $20 \mathrm{~cm} \times 15 \mathrm{~cm}$ & CMRC \\
$\mathrm{T}_{10}$ & Swarna & $20 \mathrm{~cm} \times 15 \mathrm{~cm}$ & CMRC \\
\hline
\end{tabular}

SRI: System of rice intensification; CMRC: Conventional method of rice cultivation

conventional method of rice cultivation (CMRC) on varietal performance and plant-hill spacing during kharif season 2009 and 2010 at Rice Research Station, Bankura, West Bengal, India located under red and laterite zone (western region of West Bengal). The experimental site represents low rainfall area (drought prone) of the state, with average annual rainfall of 1200-1400 $\mathrm{mm}$. The mean monthly temperature varied between $9.84^{\circ} \mathrm{C}$ in the January (coldest month) and $38.68^{\circ} \mathrm{C}$ in April (hottest month) and mean relative humidity $65 \%$ in November and $89 \%$ in July. The experimental soil was sandy loam with acidic in nature (pH: 4.9) and $0.12 \mathrm{ds} \mathrm{m}^{-1} \mathrm{EC}, 0.56 \%$ organic carbon, $36 \mathrm{~kg} \mathrm{ha}^{-1}$ available $\mathrm{P}_{2} \mathrm{O}_{5}, 193 \mathrm{~kg} \mathrm{ha}^{-1}$ available $\mathrm{K}$.

The experiment was laid out in a randomized complete block design (RCBD), replicated thrice and compared three factors in ten treatment combination (Table 1). The three factors were: rice varieties (two), plant-hill spacing (four) and crop establishment methods (two). Transplanting of younger rice seedlings (12 days old) was done in SRI and transplanting older seedling (28 and 33 days old for lalat and swarna, respectively) in CMRC. The average length of seedling at transplanting in SRI was about 10-12 cm (at about 2 leaf stage) and of seedling in CMRC was about 30-35 cm (at 4-5 leaf stage). The two rice varieties were Lalat and Swarna (MTU-7029). The plot size was $4 \mathrm{~m} \times 3 \mathrm{~m}$. Regarding fertilizer management $\mathrm{N}, \mathrm{P}_{2} \mathrm{O}_{5}, \mathrm{~K}_{2} \mathrm{O} @ 60,30,30 \mathrm{~kg}$ ha $^{-1}$ were applied [ $75 \%$ by inorganic source and $25 \%$ through organic source (vermicompost)]. Application of $1 / 4^{\text {th }}(25 \%)$ of the recommended dose of $\mathrm{N}$ and total $\mathrm{P}$ and $75 \% \mathrm{~K}$ as basal were done. Second dose of $\mathrm{N}$ $(50 \%)$ at the time of $2^{\text {nd }}$ weeding (20 DAT) was applied. Final dose of $25 \% \mathrm{~N}$ along with remaining $25 \%$ $\mathrm{K}$ at panicle initiation stage were applied. Applied F.Y.M@ $5 \mathrm{t} \mathrm{ha}^{-1}$ and incorporation of Glyricidia (leaf and twigs) as green manure@ $5 \mathrm{t} \mathrm{ha}^{-1}$ at 20 DBP (days before planting) was done.

Plant height (from ground level to the tip of the flag leaf) was taken at ripening stage based on randomly selected ten plants. The $5 \mathrm{~m}^{2}$ area in the middle of each plot was harvested for recording grain yield. Ten rice hills outside the harvested area were selected and harvested separately for recording yield parameters, viz., number of tillers hill $^{-1}$, 1000-grain weight, length of panicle $(\mathrm{cm})$ and panicle weight etc.

\section{RESULTS AND DISCUSSION}

Plant height: It was affected by the crop establishment methods (SRI and CMC). Transplanting of younger seedlings (12 days old) produced significantly taller plants than the transplanting of older seedlings (28-33 days old). Highest plant height (122.20, 115.72 and $118.9 \mathrm{~cm}$ during 2009, 2010 and in pooled, respectively) was recorded from treatment $\mathrm{T}_{3}(25 \times 25 \mathrm{~cm}$ plant-hill spacing) under SRI (Table 2) and lowest plant height $(115.42,107.57$ and $108.8 \mathrm{~cm}$ during 2009,2010 and in pooled, respectively) was obtained from $\mathrm{T}_{9}$ treatment $(20 \times 15 \mathrm{~cm}$ plant-hill spacing $)$ under conventional method of rice cultivation in case of lalat. Swarna has recorded maximum plant height (114.27, 106.37 and $110.2 \mathrm{~cm} \mathrm{2009,} 2010$ and in pooled, respectively) at $25 \times 25 \mathrm{~cm}$ plant-hill spacing from treatment $\mathrm{T}_{7}$ under SRI and lowest plant height (107.23, 99.35 and $103.2 \mathrm{~cm} \mathrm{2009,} 2010$ and in pooled, respectively) was recorded from treatment $\mathrm{T}_{10}$

Table 2. Plant height and number of tillers hill ${ }^{-1}$ of rice varieties as influenced by SRI and CMRC.

\begin{tabular}{lcccccc}
\hline \multirow{2}{*}{ Treatments } & \multicolumn{3}{c}{ Plant height $(\mathbf{c m})$ at harvest } & \multicolumn{3}{c}{ No. of tillers hill $^{-1}$} \\
\cline { 2 - 6 } & $\mathbf{2 0 0 9}$ & $\mathbf{2 0 1 0}$ & Pooled & $\mathbf{2 0 0 9}$ & $\mathbf{2 0 1 0}$ & Pooled (No. of hills $^{-2}$ ) \\
\hline $\mathrm{T}_{1}$ & 117.5 & 110.8 & 114.1 & 7.64 & 6.87 & $7.23(33)$ \\
$\mathrm{T}_{2}$ & 119.6 & 113.5 & 116.5 & 10.75 & 10.24 & $10.35(25)$ \\
$\mathrm{T}_{3}$ & 122.2 & 115.7 & 118.9 & 17.56 & 16.75 & $16.82(16)$ \\
$\mathrm{T}_{4}$ & 116.8 & 110.8 & 113.8 & 23.35 & 22.27 & $22.74(11)$ \\
$\mathrm{T}_{5}$ & 113.2 & 103.6 & 108.2 & 9.42 & 8.69 & $9.05(33)$ \\
$\mathrm{T}_{6}$ & 112.4 & 104.4 & 108.4 & 13.78 & 12.60 & $13.10(25)$ \\
$\mathrm{T}_{7}$ & 114.2 & 106.3 & 110.2 & 22.62 & 21.18 & $21.26(16)$ \\
$\mathrm{T}_{8}$ & 110.8 & 103.9 & 106.3 & 28.94 & 26.54 & $27.14(11)$ \\
$\mathrm{T}_{9}$ & 115.4 & 107.5 & 108.8 & 6.78 & 6.57 & $6.67(33)$ \\
$\mathrm{T}_{10}$ & 107.2 & 99.3 & 103.2 & 8.77 & 8.33 & $8.42(33)$ \\
S.Em ( \pm ) & 2.30 & 2.71 & 2.52 & 1.80 & 1.51 & 1.78 \\
C.D. (0.05) & 6.83 & 8.07 & 7.58 & 5.35 & 4.48 & 5.32 \\
\hline
\end{tabular}

SRI: System of rice intensification $\left(\mathrm{T}_{1}\right.$ to $\left.\mathrm{T}_{8}\right)$ CMRC: Conventional method of rice cultivation $\left(\mathrm{T}_{9}\right.$ and $\left.\mathrm{T}_{10}\right)$ 
Table 3. Number of matured panicles $\mathrm{m}^{-2}$, 1000-grain weight and panicle length of rice varieties as influenced by SRI and CMRC.

\begin{tabular}{|c|c|c|c|c|c|c|c|c|c|}
\hline \multirow{2}{*}{ Treatments } & \multicolumn{3}{|c|}{ No. of matured panicles $\mathrm{m}^{-2}$} & \multicolumn{3}{|c|}{ 1000-grain weight (g) } & \multicolumn{3}{|c|}{ Panicle length (cm) } \\
\hline & 2009 & 2010 & Pooled & 2009 & 2010 & Pooled & 2009 & 2010 & Pooled \\
\hline $\mathrm{T}_{1}$ & 234.3 & 215.3 & 224.2 & 21.83 & 20.23 & 21.03 & 24.19 & 23.51 & 23.82 \\
\hline $\mathrm{T}_{2}$ & 256.7 & 248.2 & 252.4 & 22.25 & 22.50 & 22.21 & 26.16 & 24.68 & 25.35 \\
\hline $\mathrm{T}_{3}$ & 272.9 & 256.1 & 264.3 & 22.34 & 23.27 & 22.62 & 26.83 & 25.45 & 26.14 \\
\hline $\mathrm{T}_{4}$ & 240.8 & 237.3 & 239.0 & 22.84 & 23.50 & 23.17 & 26.10 & 24.22 & 25.16 \\
\hline $\mathrm{T}_{5}$ & 295.8 & 277.6 & 285.4 & 19.53 & 20.17 & 19.74 & 24.70 & 23.92 & 24.31 \\
\hline $\mathrm{T}_{6}$ & 330.5 & 315.8 & 322.1 & 20.25 & 20.33 & 21.25 & 25.72 & 24.05 & 24.12 \\
\hline $\mathrm{T}_{7}$ & 355.9 & 331.6 & 343.5 & 20.87 & 20.85 & 20.86 & 26.63 & 25.12 & 25.84 \\
\hline $\mathrm{T}_{8}$ & 300.3 & 285.5 & 292.6 & 21.58 & 22.33 & 21.82 & 25.23 & 23.64 & 24.43 \\
\hline $\mathrm{T}_{9}$ & 212.1 & 205.4 & 207.7 & 21.56 & 19.60 & 20.58 & 23.92 & 20.23 & 21.92 \\
\hline $\mathrm{T}_{10}$ & 271.4 & 263.2 & 267.1 & 19.42 & 19.97 & 19.59 & 22.54 & 19.74 & 21.12 \\
\hline $\operatorname{S.Em~(\pm )~}$ & 9.87 & 5.45 & 6.63 & 1.27 & 1.22 & 1.26 & 0.84 & 2.01 & 1.25 \\
\hline C.D. (0.05) & 29.31 & 16.83 & 19.68 & NS & NS & NS & 2.50 & 5.96 & 3.72 \\
\hline
\end{tabular}

SRI: System of rice intensification $\left(\mathrm{T}_{1}\right.$ to $\left.\mathrm{T}_{8}\right)$ CMRC: Conventional method of rice cultivation $\left(\mathrm{T}_{9}\right.$ and $\left.\mathrm{T}_{10}\right)$

$(20 \times 15 \mathrm{~cm}$ plant-hill spacing) under CMRC. This might be due to development of better root system (length and growth) by younger seedlings under SRI which in turn produced vigorous and taller plants. It was also reported by Uphoff in the year of 2002 . Vijayakumar et al. (2006) reported that rice plants were taller under SRI as compared to CMRC.

Number of tillers hill ${ }^{-1}$ : It was significantly affected during both the years and in pooled data is presented in table 2. The maximum no. of tillers hill $^{-1}$ were recorded from treatment $\mathrm{T}_{4}$ (lalat at $30 \times 30 \mathrm{~cm}$ spacing) and $\mathrm{T}_{8}$ (swarna at $30 \times 30 \mathrm{~cm}$ spacing) under SRI. The minimum no. of tillers hill ${ }^{-1}$ were obtained from treatment $\mathrm{T}_{9}$ (lalat at $20 \times 15 \mathrm{~cm}$ spacing) and $\mathrm{T}_{10}$ (swarna at $20 \times 15 \mathrm{~cm}$ spacing) under traditional method of cultivation. The number of tillers hill ${ }^{-1}$ were higher at $30 \times 30 \mathrm{~cm}$ spacing (wider) under SRI than at $20 \times 15 \mathrm{~cm}$ spacing (narrow) under conventional method of cultivation by about 3.3 times. It might be due to production of relatively more tillers at wider spacing as compared to narrow spacing, because of advantage of space, nutrition and sunlight at wider spacing. Wider spacing was adopted in SRI, which provides ample light and soil space - this situation encourages luxuries root growth and more number of tillers per hill supporting synergistically (DRR, 2011).

Number of mature panicles $\mathbf{m}^{-2}$ : It was statistically significant. In case of lalat, highest no. of matured panicles $\mathrm{m}^{-2}(272.9,256.1$ and 264.3 during both years and in pooled data, respectively) were recorded from treatment $\mathrm{T}_{3}(25 \times 25 \mathrm{~cm}$ spacing $)$ and it was statistically at par with treatment $\mathrm{T}_{2}(20 \times 20 \mathrm{~cm}$ spacing $)$ under SRI (Table 3). Lowest number of matured panicles $\mathrm{m}^{-2}$ (212.1, 205.4 and 207.7 during 2009, 2010 and in pooled, respectively) were obtained from treatment $\mathrm{T}_{9}(20 \times 15 \mathrm{~cm}$ spacing $)$ under $\mathrm{CMC}$ and was at par with treatment $T_{1}(20 \times 15 \mathrm{~cm}$ spacing $)$ and $T_{4}(30 \times$ $30 \mathrm{~cm}$ spacing) under SRI and it was significantly lower than other treatments. In case of swarna, maximum no. of matured panicles $\mathrm{m}^{-2}(355.9,331.6$ and
343.5 during 2009, 2010 and in pooled data, respectively) were recorded from treatment $\mathrm{T}_{7}(25 \times 25 \mathrm{~cm}$ spacing $)$ and it was significantly higher than other treatments and statistically at par with treatment $\mathrm{T}_{6}(20 \times 20 \mathrm{~cm}$ spacing) under SRI. Lowest no. of matured panicles $\mathrm{m}^{-}$ ${ }^{2}$ (271.4, 263.2 and 267.1 during 2009, 2010 and in pooled, respectively) were obtained from treatment $T_{10}$ $(20 \times 15 \mathrm{~cm}$ spacing) under CMRC and it was statistically at par with treatment $\mathrm{T}_{5}(20 \times 15 \mathrm{~cm}$ spacing $)$ and $\mathrm{T}_{8}$ $\left(30 \times 30 \mathrm{~cm}\right.$ spacing) under SRI. Number of tillers hill ${ }^{-}$ ${ }^{1}$ was more at $30 \times 30 \mathrm{~cm}$ spacing due to wider spacing, but number of hills $\mathrm{m}^{-2}$ was decrease. 11 hills $\mathrm{m}^{-2}$ were accommodated at $30 \times 30 \mathrm{~cm}$ spacing as compared to 33 hills $\mathrm{m}^{-2}$ at $20 \times 15 \mathrm{~cm}$ spacing. Sharma and Masand (2008) observed that lowest number of mature panicles $\mathrm{m}^{-2}$ was obtained from conventional method of rice cultivation (CMRC) and highest number of matured panicles $\mathrm{m}^{-2}$ was recorded from SRI $(25 \times 25 \mathrm{~cm}$ spacing).

1000-grain weight: It was not significantly affected by the SRI and CMRC. It is more or less genetically controlled character. However, the value of 1000-grain weight was higher at $30 \times 30 \mathrm{~cm}$ spacing under SRI than at $20 \times 15 \mathrm{~cm}$ spacing under CMRC.

Length of panicle: Experimental results also revealed that the length of panicle was statistically significant and affected by the methods of establishment (SRI and CMRC). In case of lalat the highest length of panicle (26.83, 25.45 and $26.14 \mathrm{~cm}$ during 2009, 2010 and in pooled, respectively) was obtained from treatment $\mathrm{T}_{3}$ $(25 \times 25 \mathrm{~cm}$ spacing $)$ under SRI and it was statistically at par with treatment $T_{2}$ and $T_{4}$ and significantly higher than treatment $T_{9}$ and $T_{1}$. In case of swarna, maximum length of panicle $(26.63,25.12$ and $25.84 \mathrm{~cm}$ during 2009,2010 and in pooled, respectively) was recorded from treatment $\mathrm{T}_{7}(25 \times 25 \mathrm{~cm}$ spacing $)$ under $\mathrm{SRI}$ and lowest panicle length was obtained from treatment $\mathrm{T}_{10}$ $(20 \times 15 \mathrm{~cm}$ spacing $)$ under CMRC. It was statistically at par with treatment $T_{5}$ and significantly lower than other treatment (Table 3). 
Table 4. Panicle weight and grain yield of rice varieties as influenced by SRI and CMRC.

\begin{tabular}{|c|c|c|c|c|c|c|}
\hline \multirow{2}{*}{ Treatments } & \multicolumn{3}{|c|}{ Panicle weight (g) } & \multicolumn{3}{|c|}{ Grain yield (t ha $\left.{ }^{-1}\right)$} \\
\hline & 2009 & 2010 & Pooled & 2009 & 2010 & Pooled \\
\hline $\mathrm{T}_{1}$ & 2.15 & 1.98 & 2.06 & 3.84 & 3.48 & 3.65 \\
\hline $\mathrm{T}_{2}$ & 2.69 & 2.61 & 2.62 & 4.43 & 4.22 & 4.32 \\
\hline $\mathrm{T}_{3}$ & 3.15 & 3.06 & 3.10 & 4.98 & 4.42 & 4.69 \\
\hline $\mathrm{T}_{4}$ & 2.89 & 2.84 & 2.84 & 4.11 & 3.80 & 3.92 \\
\hline $\mathrm{T}_{5}$ & 2.46 & 2.36 & 2.41 & 4.73 & 4.20 & 4.46 \\
\hline $\mathrm{T}_{6}$ & 2.97 & 2.82 & 2.86 & 5.58 & 5.16 & 5.36 \\
\hline $\mathrm{T}_{7}$ & 3.37 & 3.28 & 3.31 & 6.07 & 5.66 & 5.86 \\
\hline $\mathrm{T}_{8}$ & 3.08 & 2.95 & 3.01 & 4.97 & 4.47 & 4.69 \\
\hline $\mathrm{T}_{9}$ & 1.97 & 1.84 & 1.90 & 3.55 & 3.23 & 3.38 \\
\hline $\mathrm{T}_{10}$ & 2.22 & 2.15 & 2.17 & 4.32 & 4.18 & 4.25 \\
\hline $\operatorname{S.Em~}( \pm)$ & 0.21 & 0.11 & 0.20 & 0.24 & 0.18 & 0.22 \\
\hline C.D. (0.05) & 0.63 & 0.33 & 0.59 & 0.73 & 0.55 & 0.66 \\
\hline
\end{tabular}

SRI: System of rice intensification $\left(\mathrm{T}_{1}\right.$ to $\left.\mathrm{T}_{8}\right)$ CMRC: Conventional method of rice cultivation $\left(\mathrm{T}_{9}\right.$ and $\left.\mathrm{T}_{10}\right)$

Panicle weight: It was also significantly affected. The highest panicle weight was recorded at $25 \times 25 \mathrm{~cm}$ spacing under SRI and lowest at $20 \times 15 \mathrm{~cm}$ spacing under conventional method of cultivation in case of lalat and swarna varieties both (Table 4). The highest value of panicle weight $(3.37,3.28$ and $3.31 \mathrm{gm}$ in case of swarna and $3.15,3.06$ and $3.10 \mathrm{gm}$ in case of lalat during both years and in pooled data, respectively) were recorded at $25 \times 25 \mathrm{~cm}$ spacing under SRI. Lowest value of panicle weight $(2.22,2.15$ and $2.17 \mathrm{gm}$ in case of swarna and 1.97, 1.84 and $1.90 \mathrm{gm}$ in case of lalat during 2009, 2010 and in pooled data, respectively) were obtained at $20 \times 15 \mathrm{~cm}$ spacing under conventional method of rice cultivation (Table 4). Moreover, the panicle length and panicle weight of rice crop were more with SRI than CMRC. Similar findings were observed by Sharma and Masand (2008). Grain yield: During kharif season 2009, 2010 and in pooled data (Table 4) revealed that the grain yield was significantly affected by crop establishment methods (SRI and CMRC). Lalat variety yielded highest grain yield (4.98, 4.42 and $4.69 \mathrm{t} \mathrm{ha}^{-1}$ during 2009, 2010 and in pooled, respectively) and it was obtained from $\mathrm{T}_{3}$ $(25 \times 25 \mathrm{~cm}$ spacing $)$ under SRI and it was statistically at par with treatment $\mathrm{T}_{2}(20 \times 20 \mathrm{~cm}$ spacing $)$ and significantly higher than other treatments. Where as, the lowest grain yield $\left(3.55,3.23\right.$ and $3.38 \mathrm{t} \mathrm{ha}^{-1}$ during 2009,2010 and in pooled, respectively) was recorded from treatment $T_{9}(20 \times 15 \mathrm{~cm}$ spacing $)$ under traditional method of rice cultivation. It was statistically at pat with treatment $T_{1}(20 \times 15 \mathrm{~cm}$ spacing $)$ and $T_{4}(30 \times$ $30 \mathrm{~cm}$ spacing) under SRI. Swarna yielded maximum grain yield $\left(6.07,5.66\right.$ and $5.86 \mathrm{t} \mathrm{ha}^{-1}$ during 2009 , 2010 and in pooled, respectively) from treatment $\mathrm{T}_{7}$ $(25 \times 25 \mathrm{~cm}$ spacing) under SRI and it was statistically at par with $\mathrm{T}_{6}$ treatment $(20 \times 20 \mathrm{~cm}$ spacing $)$ under SRI. Where as, the lowest grain yield (4.32, 4.18 and $4.25 \mathrm{t} \mathrm{ha}^{-1}$ during 2009, 2010 and in pooled, respectively) was recorded from treatment $\mathrm{T}_{10}(20 \times 15 \mathrm{~cm}$ spacing) under CMRC and it was statistically at par with treatment $T_{5}(20 \times 15 \mathrm{~cm}$ spacing $)$ and $T_{8}(30 \times$
$30 \mathrm{~cm}$ spacing) under SRI. This might be due to improved synthesis and translocation of metabolites to various reproductive structures of rice plant and better distribution of it's into grain would always results in higher grain yield of rice under SRI. This was agreed with Barla and Kumar (2011) as they reported that significantly more grain yield of rice was recorded under SRI than conventional method of rice cultivation.

Increased grain yield under SRI is mainly due to the synergistic effects of modification in the cultivation practices such as use of young and single seedling per hill, frequent loosening of the top soil to stimulate aerobic soil conditions. Transplanting of very young seedling usually 10-12 days old, preserves it's potential for tillering and rooting, which was reduced if transplanted after the occurrence of fourth phyllochron. This might be due to combination of plant, soil, nutrient and water management practices followed in SRI increased the root growth along with increase in productive tillers, panicle length, panicle weight, grain filling and higher grain weight that ultimately resulted in higher grain yield. Use of conoweeder might improve aeration and health status of the soil due to incorporation of weed biomass in soil under SRI. Crop growth has been emphasized by different proponents of SRI as reported by Uphoff (2002) and resulting in increased crop vigour and yield attributes.

\section{Conclusion}

Swarna variety (MTU 7029) has yielded more grain yield than Lalat variety at $25 \times 25 \mathrm{~cm}$ spacing under system of rice intensification (SRI) as compared to conventional method of cultivation in red and laterite zone of West Bengal. Less time was required for transplanting rice seedlings under SRI. It lowered the man-day requirement for transplanting rice seedlings under SRI as compared to CMC. Transplanting of one seedling hill ${ }^{-1}$ in SRI significantly lower seed requirement as compared to conventional method of 
rice cultivation ( 3 seedlings hill $^{-1}$ ). Higher grain yield was recorded from SRI as compared to CMRC. Thus, SRI technology has potential in increasing more grain yield. It saves seed requirement and irrigation water and chemical fertilizer than the traditional method of cultivation. Rice cultivation is more sustainable and profitable for the farmers under SRI in the red and laterite zone of West Bengal, India.

\section{ACKNOWLEDGEMENTS}

The first author would like to thanks Dr. A. Biswas, Joint Director of Agriculture (Mycology and Plant Pathology), Mr. K. K. Bhadra, EB-V, Dr. G. K. Mallick, Asstt. Botanist, RRS, Bankura and Dr. P. K. Maity, Chief Agronomist, FCRS, Burdwan and Dr. P. Bhattacharya, Director of Agriculture, Department of Agriculture, Govt. of West Bengal, Writers' Building, Kolkata-700 001, West Bengal and also to Prof. B. K. Mandal, retired Professor and former Head, Department of Agronomy, Bidhan Chandra Krishi Viswavidyalay, Mohanpur, Nadia, West Bengal, India for their valuable guidance and encouragement during the period of this research programme.

\section{REFERENCES}

Barla, S. and Kumar, S. S. (2011). Evaluation of rice establishment techniques in Jharkhand platue. Oryza. 48 (1): 79-80.

DRR (Directorate of Rice Research). (2011). System of Rice Intensification: Enhancing input use efficiency in rice, DRR Technical Bulletin No. 58/2011: 27

Jana, K., Mallick, G. K., Das, S. K. and Puste, A. M. (2015). Performance of rice varieties in system of rice intensification under red and laterite zone of West Bengal, India. National symposium on 'Food and nutrition: Need for the future', Institute of Agricultural Science, Kolkata, 25-27 Feb. : 53

Mc Donald, A.J., Hobbes, P.R. and Riha, S.J. (2006). Does the system of rice intensification outperform conventional best management? A synopsis of the empirical record. Field crop Research, 96 (1): 31-36.

Sato, S. and Uphoff, N. (2007). A review of on-farm evaluations of system of rice intensification methods in Eastern Indonesia. CAB Reviews: Perspectives in Agriculture, Veterinary Science. Nutrition and Natural Resources, 2: 12.

Satyanarayana, A. (2004). The System of Rice Intensification: Evaluation in Andhra Pradesh. World Rice Research Conference, Tokoyo-Tsukuba, 4-7 Nov.

Sharma, P. K. and Masand, S. S. (2008). Evaluation of system of rice intensification in a high rainfall area of North-Western Himalayas. Oryza. 45 (3): 206-211.

Sinha, S.K. and Talati, J. (2005). Impact of system of rice intensification (SRI) on rice yields: Results of a new sample study in Purulia district, West Bengal. Session on SRI at the $4^{\text {th }}$ Annual IWMI TATA partners Meet on 'Bracing up for the future' Anand, Institute for Rural Management, 24-26 Feb.

Sinha, S.K. and Talati, J. (2007). Productivity impacts of the system of rice intensification (SRI): a case study in West Bengal, India. Agr.Water Manage., 87: 55-60.

Thiyagarajan, T.M., Senthilkumar, K., Priyadarshini, R., Ezhilrani, K., Jothirani, S., Davud, P.M.M., Sundarsingh, J., Muthusankaranayanana, A., Haib Hengsdi, J.K. and Bindraba Prem, S. (2005). System of rice intensification (SRI) for enhanced water and Rice productivity in Tamil Nadu, India. Session on SRI at the $4^{\text {th }}$ Annual IWMI TATA partners Meet on 'Bracing up for the future' Anand, Institute for Rural Management, 24-26 Feb.

Uphoff, N. (2002). System of Rice Intensification (SRI) for enhancing the productivity of land, labour and water. J. Agr. Resource Manage., 1: 43-49.

Vijayakumar, M., Ramesh, S., Prabhakaran, N.K., Subbain, P. and Chandrasekaran, B. (2006). Influence of system of rice intensification (SRI) practices on growth characters, days to flowering, growth analysis and labour productivity of rice. Asian J. Plant Sci., 5: 984-989. 